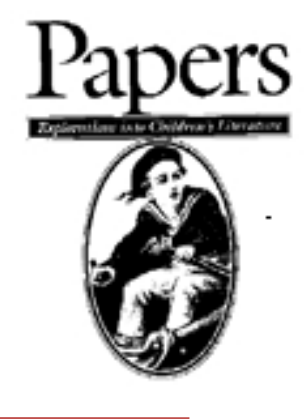

\title{
Growing up Australian: The National Imaginary in School Readers
}

\author{
Jane McGennisken
}

\section{St Mary's College, Hobart}

During the first half of the twentieth century, School Readers were intended to propagate a national imagination. The symbolic association of the child and the nation is instrumental in this regard. Indeed, such an association is a familiar element in Australian children's literature of the late nineteenth and early twentieth centuries. Invested in the innocence of the young and the child's naive adventurous spirit is the potential of a new nation. The sacredness associated with the figure of the child, in Western thinking more broadly, and in School Readers specifically, circulates around the child figure's naturalised innocence. This paper considers the Readers' literary and visual production of the child/nation. These school reading books present C. E. W. Bean's Anzac prototype in 'The Youngster', but also, in performing anxieties about a preferred story of national growth, include stark illustrations of dead, abandoned and lost children. Where the child is read metonymically for the nation; the child is contradictorily asked to embody innocence (and therefore vulnerability) at the same time he or she appears confidently assured about the future.

From the late 1800s to the 1950s, the 'School Reader', a graded and illustrated anthology of stories, poems, essays and extracts from longer works, was an indispensable part of Australian classroom life. Until the twentieth century in Australia, the Readers were either those reading books developed as part of the Irish National System (a non-denominational educational program designed to placate both Catholics and Protestants), or books from other British series based on the successful, and potentially lucrative, Irish model. Due to their origins in the northern hemisphere, these Readers were regularly and loudly criticised for their lack of local content. To address this shortcoming, as well as in response to reforms of Australian education systems, the various state education departments began producing their own reading series in the early twentieth century, beginning with the New Australian School Series of New South Wales somewhere around the turn of the century, through to the Tasmanian Readers published in $1933 .{ }^{1}$ The local Readers were regularly revised and reprinted so that some were in use well into the 1950s and 1960s. ${ }^{2}$ The Readers provided exercises in spelling, poetry recitation, composition and comprehension. They also offered lessons in geography, history, health, and, above all, in the appreciation of great or otherwise important works of literature (where these literary selections were clearly influenced by Neo-Herbartian ideas about the moral purpose of education). Although education had been free, secular and compulsory in the colonies since the 1870 s and 1880s (and although education departments were and remain 
state-based rather than national), Australian Federation provided an added impetus for governments, educational administrators and School Reader editorial committees to begin teaching national citizenship in earnest.

The idealised child of nation, or the child-nation, is represented powerfully in an image reproduced as the frontispiece of The Victorian Readers Second Book - a painting entitled The Age of Innocence by English artist Sir Joshua Reynolds (Figure 1). As Anne Higgonet attests, 'it was paintings like The Age of Innocence that captured the modern western visual imagination and became the foundation of what we assume childhood looks like' (1998, p.23). The child's fragility, her translucent skin and her seemingly naive ignorance of a viewer all contribute to the ideas about childhood and innocence that pervade this image. The child dominates the frame. But while she is prominent in the foreground, the trees, land, sky and clouds serve to emphasise her miniaturised child status. She is vulnerable at the same time as she is so powerfully central. Her hands are crossed protectively across her chest, allowing her this helplessness and innocence, despite her naturalness, the confidence with which she dominates the scene. This naturalness is borne out by the tiny toes directed toward the viewer. Indeed, as Higgonet writes, 'the child belongs so comfortably in nature that she doesn't need shoes' (p.15). Interestingly, the date attributed to this art work, 1788, coincides with the arrival of the English First Fleet, the beginning of a white colonial history in Australia. It is the preferred version of this white history, and what therefore must be written out or written over, that is so closely and complicatedly bound up with the literary and visual production of children and childhood in school Readers. In this way, Clare Bradford aptly terms school Readers 'mechanisms for forgetfulness' (2001, p.21). The significance of the Age of Innocence then is twofold. It suggests a young and blameless Australia in its characterisation of unblemished childhood

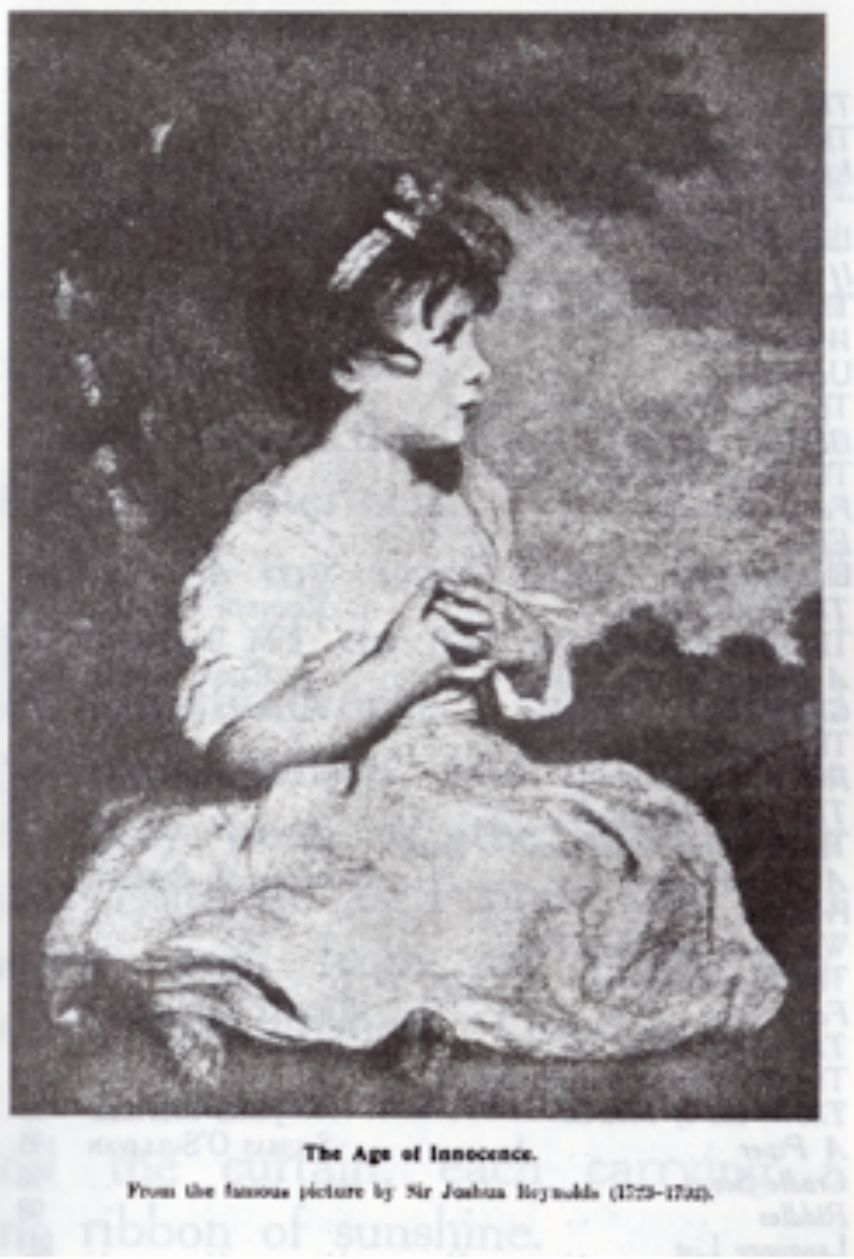

Figure 1. The Age of Innocence, Frontispiece, The Victorian School Readers Second Book, 1930 innocence. 


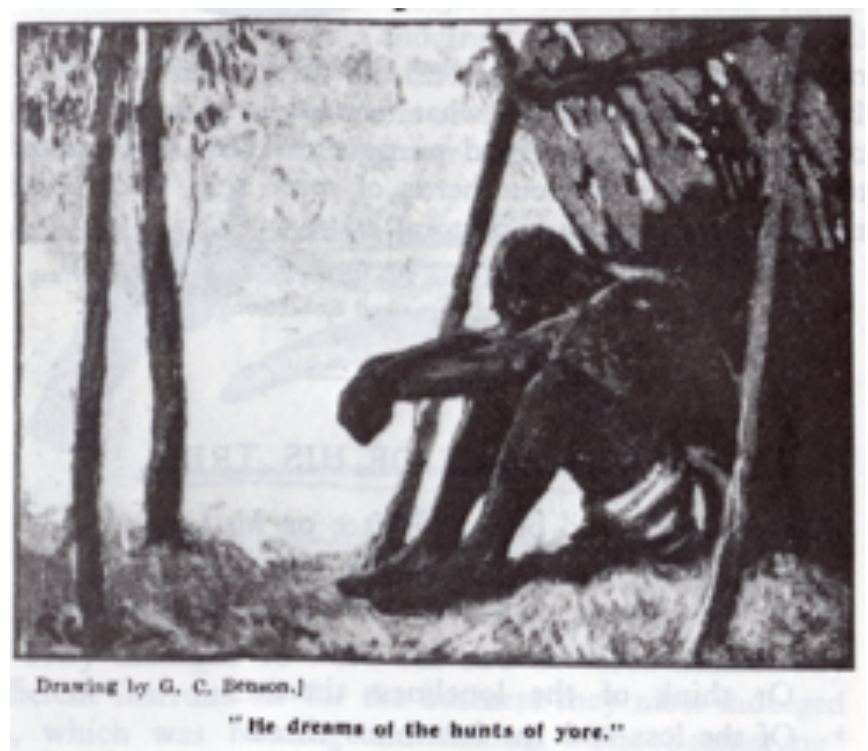

Figure 2. 'He Dreams of the Hunts of Yore' The Victorian Reading-Books Eighth Book, 1928
As mechanisms for forgetting, School Readers present the inevitability of a white future against a fading black past. Illustrating this, the drawing accompanying Henry Kendall's 'The Last of His Tribe' (Figure 2) can be read alongside John Rowell's illustration of a white bush schoolboy (Figure 3). Where the semiotic fields of Aboriginality and Australian childhood intersect or overlap, the national imaginary produces for itself a positive apperception of its own indigeneity. Images of the white indigene are particularly important in School Readers where the child reader him or herself is positioned to identify with the one who appears in the picture. So, while the Aboriginal man in Benson's drawing bends his head down, looking toward the ground, or indeed, not seeing at all; the bush schoolboy, also in side profile, rests his arms around his knees, contented and expectant. Though they both have conspicuously naked feet and both adopt similar sitting positions, the man is a picture of dejection while the boy is optimistic, assured. The white child raises his head and looks up, to the future. The images are framed in very similar ways. Yet, while the Aboriginal man retreats into a shelter, the white child leans against a young eucalypt.

Rowell's illustration accompanies Myra Morris's poem 'The Bush Schoolboy', a simple portrayal of the authentic Australian child as he (and sometimes she) is popularly represented across School Readers, a child entirely at home in 'the bush'. 3 This child, a 'barelegged urchin', is shaped by a buoyant, optimistic spirit. History does not concern him: 'he laughs to feel the cool, crisp grasses crunch beneath his careless feet' (1929, p.15). Any alternative reading of the past, and any discomfiting spectres this might raise, is elided by the logic of the new native. Yet the image of the white indigene is often troubled by this same repressive logic. In Rowell's illustration the rabbit at the left of the frame is an interesting inclusion. Why picture a rabbit (rather than, for example, an iconic kangaroo - à la Dot and the Kangaroo $^{4}$ in this typical Australian bush scene? The rabbit as synecdoche, in suggesting the success of a feral species in reproducing itself and in so doing, degrading the landscape, cannot be separated from the destruction

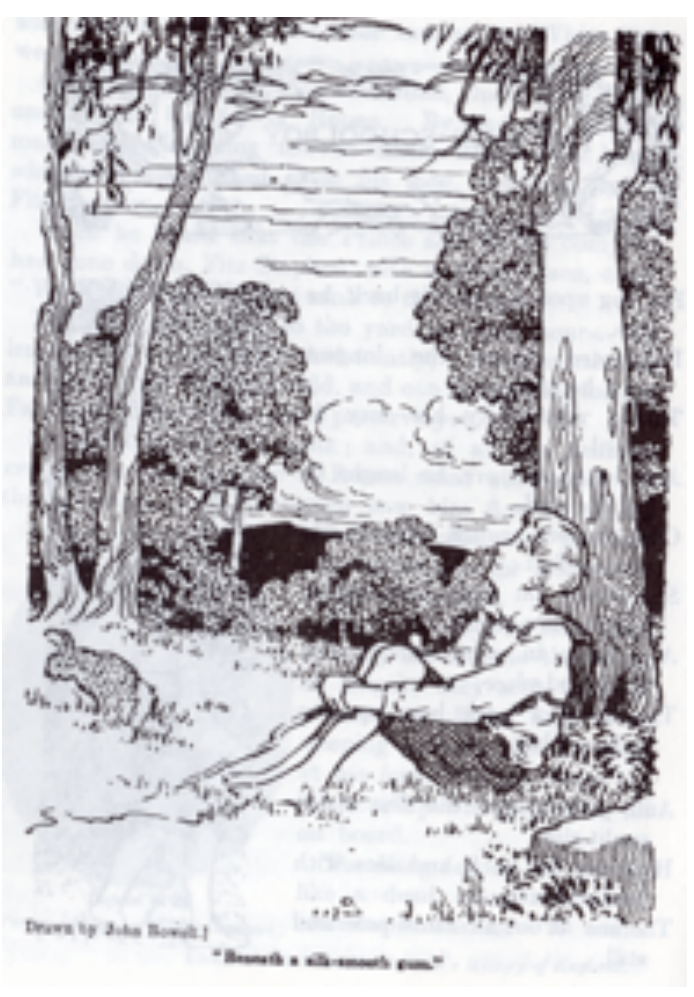

Figure 3. 'Beneath a Silk-Smooth Gum' The Victorian Readers Sixth Book, 1929 
for which it is so renowned. If the rabbit and the white boy of this picture are equally new natives, both are therefore implicated in a story of damage and devastation.

Another drawing of a 'bush boy', also by John Rowell, appears in The Victorian Readers Sixth Book (Figure 4). Illustrating Francis Hartigan's poem 'Calling to me', the caption beneath the image is instructive. It reads: 'Glad-hearted and free' (1929, p. 95). And, indeed, the picture presents another child entirely safe within a lush bush environment. He is seemingly grown out of the land itself (his feet hidden among the ferns along the creek bank). He is the kind of native child described by Mary Fullerton in her Bark House Days reminiscences: 'The gallery was full of children all grown along the creek' (1930, p.40). ${ }^{5}$ In carrying a stick so jauntily over his left shoulder, with his head and upper body twisted around as though to give directions to his presumed followers, he is an adventurer and leader of men cast according to the role of the Australian pioneer. Although he carries only a stick (a play gun, a walking staff), he is nevertheless armed, and therefore confident, in his encounter with the wilderness. The boy in this illustration is, in Ethel Turner's words, a fine example of 'the spirited, single-hearted, loyal ones who alone can "advance Australia"” (1994, p.8).

\section{A Bush Education}

Advancing the nation was undoubtedly perceived as one of the most important aims of the School Reader project. As Stephen Heathorn argues in his study of contemporaneous British School Readers, the reading of specially prepared reading books was integral to teaching English children how to become national citizens: "They provided root meanings for abstract concepts of identification ...

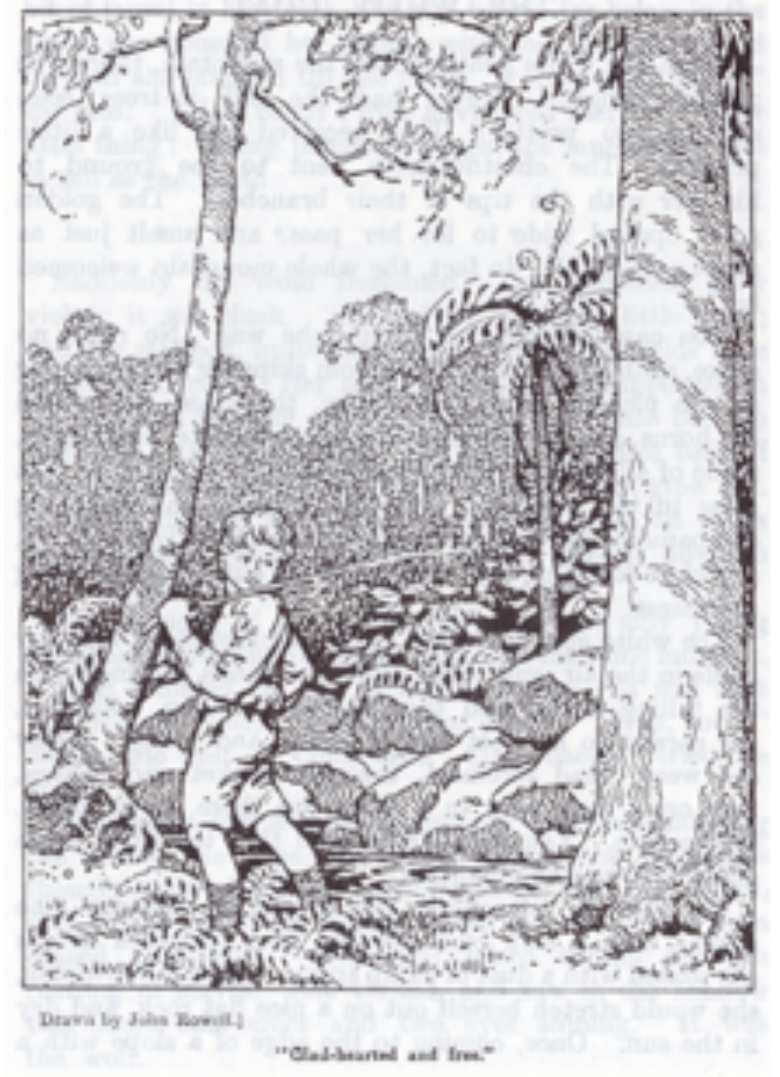

Figure 4. 'Glad-hearted and Free' The Victorian Readers Sixth Book, 1929 such as the 'nation', 'home', and 'race', and structured those meanings in a system of images and connected symbols (a 'syntax of identity') through historical, geographical and literary narratives" (2000, p.20). In the Australian series, the child entrusted with the nation's future is a white native son (or, to a lesser degree, a daughter), one courageous enough to take on the land, its Aboriginal peoples and most importantly, the task of enacting a particular story of origins, development and maturation. While it is not possible to consider them in detail here, some examples of these stories as they appear in various Australian reading series include Samuel Carter's 'An Adventure with the Blacks', Conrad Sayce's 'An Adventure with a Snake', the heroics of Frank Hawson in 'A Brave Boy', Grace Bussell in 'A Brave Australian Girl', and the boy heroes of the stories 'Sailor' and 'Pincher'. 
In both 'Sailor' and 'Pincher', leadership traits are cultivated and expressed in response to nature's vagaries. Learning experiences in the country can be costly, yet it follows that surviving an education in the bush develops those characteristics expected in the nation's young. 'Sailor' and 'Pincher', although ostensibly concerned with the loyalty of faithful dogs, are equally revealing in terms of their representation of quick-thinking, indomitable child heroes. In both of these fictions, boys who take action thwart impending disaster. These stories reiterate codings of maleness and leadership born of the ability to navigate the Australian bush.

'Pincher' from Victorian Readers Fifth Book (originally published in the South Australian school magazine The Children's Hour) is set on the Murray River. When two children are marooned on a small island amid rising floodwaters, the efforts of a boy raised in the bush are crucial to survival. Demonstrating the most important lesson of a bush education, Tom does not underestimate the power of nature. He recognises that unless help arrives soon, he and his sister will be drowned. As a boy, and therefore as a potential leader of the nation, Tom is unwilling to accept such a fate: "WWhat can I do to get us out of this fix?" Tom said to himself' (1930, p.167). In a marked contrast with his younger sister who playfully and childishly likens their situation to that of shipwrecked sailors, Tom is decisive and resourceful, even as his plan could result in the sacrifice of a dear friend. Recognising their beloved dog Pincher as their only hope of rescue, Tom throws Pincher into the current 'with all his strength' and with sticks and stones he heads the dog off to the opposite bank. Fortunately for Tom, Pincher successfully crosses the river and goes to the farm for some rather timely help.

The often contradictory role of the bush, as either a malevolent force or as educator (and sometimes as both), is nevertheless a fundamental ingredient in defining an Australian national identity and culture. Nowhere is this more apparent than in C. E. W Bean's 'The Youngster', published in The Victorian Readers Fifth Book. 'The Youngster' values a bush education as integral to a boy's transformation into a man and provides the most powerful example of the superiority of bush children versus their city-educated counterparts: 'Many of the youngsters along the Darling Bank had not seen much more of the world than this; and they might seem a little simple in the superficial lore of the cities [...] But they could teach the city man for a month things in which he is a babe' (1930, p.68). Interestingly, Bean's man/child inversion here is particularly relevant to the Readers' codings of national growth. The extract, from The "Dreadnought" of the Darling, is infused with the mythology of the bushman and the knowledge he can impart. ${ }^{6}$ Although rural schools and teachers are somewhat inferior, Bean attests to the 'masterful instruction' of the men of the 'back country', 'men who, out of an experience that has oftener been wide than happy, can teach the youngster at their feet to make of life perhaps a better success than they themselves have made of it' (p.69). Bean's 'bush boys' are adept in all those markers/myths of rural masculinity: 'The bush boy can always ride with that peculiar ease which makes him look a part of his horse' and 'his eyes are trained so that in some cases, looking down across the plain, he can see a fence when to a city man it is actually invisible' (pp.69-70). In a powerful invention of the national imagination, it is this rough country lifestyle that has and will ensure the future of the nation in moulding Australia's youth. 


\section{Swallowed by the Bush: Performing National Anxieties}

Yet there are a number of instances in which an overarching story of optimism, strength and success cannot be sustained through the figure of the child. Most profoundly, these are located in stories and images of children lost in the bush. In contrast to the children considered above, the bush-lost child is not at home in the bush, but rather, swallowed by it. This is typified in an excerpt from Henry Kingsley's The Recollections of Geoffry Hamlyn, which appears in Queensland School Readers Book $V$ in two parts, as 'How the child was lost' and 'How the child was found'. The same story appears in The New Australian School Series Third Reader (the NSW series), where it is called 'A lost child'. 'Just as in 'Pretty Dick', Marcus Clarke's renowned story of another bush-lost child, the eight year-old protagonist of this story leads an isolated, solitary existence, the child of a shepherd and his wife. He is clearly a native-born son, 'a strange wild bush child [...] and yet beautiful to look on; as active as a roe, and, with regard to natural objects, as fearless as a lion' (1913, p.17). Like the suntanned and manly boy in 'Pretty Dick', this child's superior physical attributes and courage mark him as a product of a young and virile nation. Kingsley's wild child, perhaps in mapping out the (literary) tracks other lost Australian children will inevitably follow, is sorely tempted by the forest across the river. As Peter Pierce observes, 'This is one of the earliest, and - for later writers - perhaps the most influential of all the colonial narratives of the lost child' (1999, p.14). At the end of summer, when the river is low, the child undresses and, carrying his clothes, he wades through to the other side: 'And there he stood free in the forbidden ground' (1913, p.19). In a striking exemplification of the greater narrative of national growth, the child plays out a crude re-enactment of discovery and colonisation. Here, in this foreign and forbidden landscape, is a 'new kingdom, rich beyond his utmost hopes' (p.19). In a language resonating with terms familiar from exploration notebooks and diaries, 'he would penetrate this region, and see how far it extended' [emphasis added] (p.19). Dreaming of the stories he will have for his father, suggesting the kind of relationship between Australia and the 'mother land', the child longs to show the parent the wonders of the new land: 'Perhaps he would build a new hut over here, and come and live in it!' (p.19).

Inevitably though, the child is lost. Returning to national anxieties as performed by way of these kinds of narratives, and re-performed through the function of the School Reader, a kind of double inscription, the story anatomises the child's terror and madness: 'Then he broke down, and that strange madness came on him which comes even on strong men when lost in the forest; a despair, a confusion of intellect, which has cost many a man his life. Think what it must be with a child!' (p.20). Evoking the nightmare later shared by Pretty Dick, the child walks further into the mountains 'and when the solemn morning came up again he was still tottering along the leading range, bewildered; crying, from time to time, "Mother! Mother!" still nursing his little bear, his only companion, to his bosom, and holding still in his hand a few poor flowers he had gathered the day before' (p.20).

In the second part of the story, reproduced as 'How the Child was Found' in the Queensland Reader, the narrative's focalisation shifts to the men charged with searching for the lost child. 
Unlike 'Lost in the Bush' or other stories of bush-lost children where tracking efforts are a cause for hope, if not celebration, Kingsley has his trackers despondent at the outset: 'They knew what a solemn task they had before them; and, while acting as though everything depended on speed, guessed well that their search was only for a little corpse, which, if they had luck, they would find stiff and cold under some tree or crag' (p.21).

Like other stories of lost children, traces of Aboriginal presence and absence complicate the narrative and its relationship to broader colonial discourses about progress (and threats to this). His mother suggests that the boy has crossed the river because he had seen children playing over there: 'She, knowing well that they were fairies, or perhaps worse, had warned him solemnly not to mind them; but that she had very little doubt that they had helped him over and carried him away to the forest' (p.22). It is unclear whom or what might be worse than fairies but it is possible that the mother refers here to Aboriginal children. ${ }^{9}$ Read in this way, the story suggests that an Aboriginal presence informs white Australian anxieties about legitimacy. It is significant then, that unlike other narratives of lost children, there are no 'black trackers' involved in the recovery of the child. Instead, Cecil and Sam rely on brave dog Rover to take up the trail 'like a bloodhound' (p.22). Like Pretty Dick, the child is found 'dead and stiff' (p.24). As Susan K. Martin argues, this ending (the discovery of the child by the 'better-orientated settler men'), does offer a particular kind of closure that is common to many white lost child stories, stories that can be read as recuperative: 'They release a fear of an uncanny, unmapped, unmappable landscape only to write it into a story in which the bush is made to give up its secret (the child, the space, the track), and an ending provides closure: the landscape is re-told as mapped' (2007, p.85).

In 'Lost in the Bush' though, in The Victorian School Readers Fourth Book, the landscape ultimately remains an uncanny and unmapped space. ${ }^{10}$ Its secret, three missing children, is given up only to the dispossessed Australian Aboriginal men called in to translate. 'Lost in the Bush' is particularly important to the Australian narrative tradition of lost children, both in its construction as a true story (and therefore a legitimate account of settlement), and as a perennially popular tale (we were still watching a filmic version at school in the 1980s). Yet the story, despite being so fundamental to the tradition, disrupts it in some fundamental ways. Superficially at least, as Pierce observes, the story 'might be regarded as untypical [...] for it had a happy outcome' in that survival of the children and reunification of the family are celebrated (1999, p.16). What Pierce does not adequately explore, however, is how, ultimately, the kind of recuperative ending described by Martin is doubly disavowed. While the children do survive, they are certainly no longer innocent, and in the Readers' version of events, though the family appears to be reunified, the lost child Jane is handed to one of her rescuers before she is embraced by her father. Although narrative closure would seem to provide thematic and moralistic significance in ensuring that goodness is rewarded and innocence protected, the contradictoriness of the topos, particularly as it can be read across School Readers, suggests something far more complicated and unsatisfying. Drawing again on Martin's analysis of a lost child episode in Joseph Furphy's Such is Life: 'As the successful reader of traces here, and as a representative of an extensive tradition of "Black trackers" in lost child stories, [the tracker] casts doubt on the possibility of non-Aborigines reading the landscape and, by 
extension, of settlers being capable of reading those narratives of place and nation, or national fiction, in which [Jane] is figured as future heroine' (2007, p.80).

\section{Picturing the Bush-Lost Child}

Lost children narratives reveal a kind of (im)perfect innocence, an imagined state already corrupted in the ambivalence of its literary and visual representations. Jane Duff, for instance, is both innocent and at the same time, imbued with anxieties about sexuality and both the protection, and transgression, of a bodily innocence (evidenced in the emphasis upon her undressing to provide garments with which to cover her younger brother for example). As narrative signs, illustrations of lost children all employ visual markers of the child's vulnerability and innocence, where the land and nature (as metaphor for native), threaten to consume the child, and concomitantly, what the

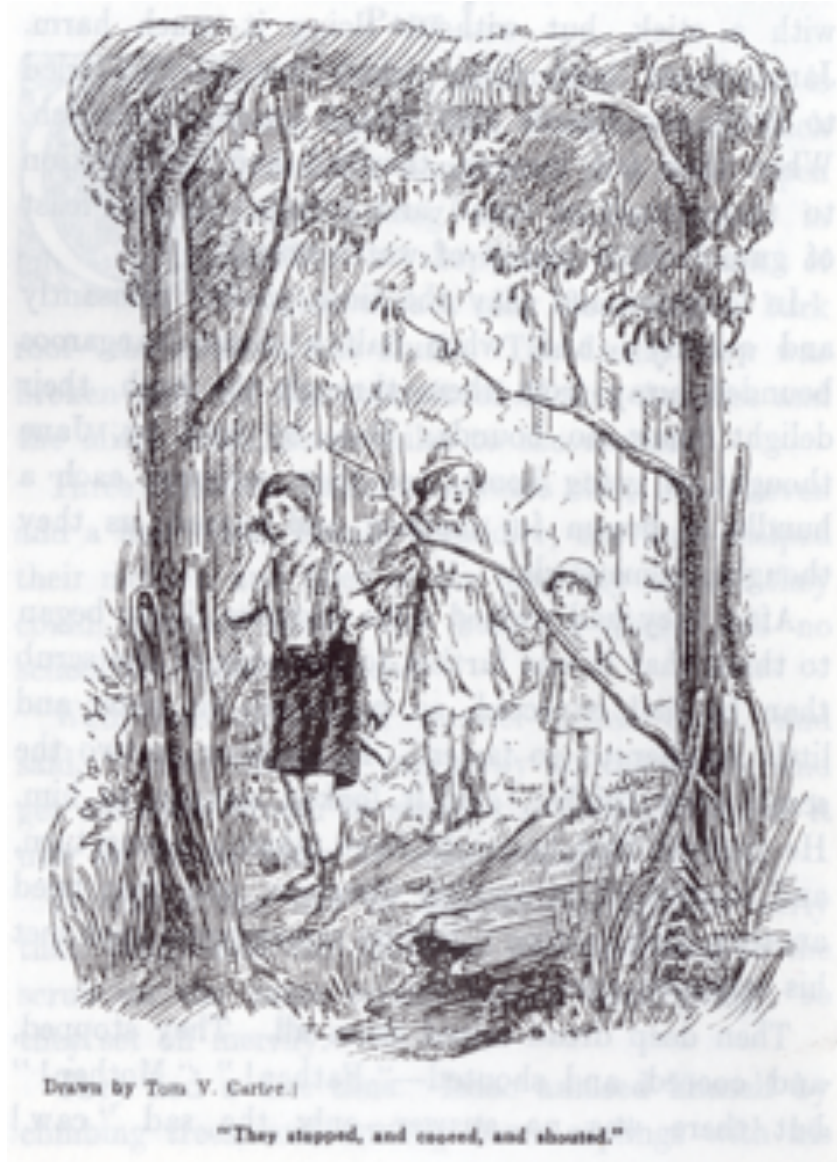

Figure 5. 'They stopped, and cooeed, and shouted', The Victorian Readers Fourth Book, 1930 child ideally represents as a white indigene - an unblemished national past and future. An encroaching wilderness and its connotations of lost innocence are central to constructions of lost children images. In concert with the written descriptions of an inviting, but deeply hostile natural environment, the illustrations play upon tropes of proximity and consumption in quite explicit ways.

In The Victorian Readers Fourth Book, Tom Carter's drawing of the Duff children lost in the bush emphasises nature's immensity and the children's relative powerlessness (Figure 5). As framing devices, the largest trees on either side of the illustration draw the viewer's eye into the image, focussing attention on the children at its centre. The bush figuratively encloses them. The canopy overhead, the trees at the side and the rotting $\log$ in the foreground encircle the children. The interaction between the children in this scene, and the relationship between these figures and the landscape, are particularly significant. His head slightly cocked to one side, hand cupped against his ear and axe at the ready, the oldest child Isaac is wary and watchful. The youngest child Frank clearly demonstrates the children's fearfulness. Holding Jane's hand, he looks up at his sister for guidance and reassurance. While Jane and Isaac are moving toward the foreground, Frank appears less certain. While their knees are bent and their feet appear caught in the act of stepping forward, Frank is at a standstill, one arm reaching back into the space from which they have apparently just exited. Where the landscape can be read according to the cost of a repressed Aboriginal story of attempted 
genocide, stories of incorporation, as Alan Lawson observes, 'function as cautionary tales for women and children who might think of straying "out of place"' (2004, p.1220). In this sense, the drawing of the children physically trapped in nature (where long, forked and naked branches stretch out across their path to actually transect the figures of Jane and Frank) reveals the danger of attempting to move beyond the safe environs of a 'known' story of Australian settlement and growth. And again highlighting Jane's symbolic significance to this story, especially 'Lost in the Bush' as exemplum, Jane is the central figure of Carter's illustration.

Illustrations of lost children, like the narrative tradition, are influenced by references to landscape as much as they are concerned with the portrayal of corrupted childhood innocence. Indeed, the image of the child abandoned in and by the Australian landscape (the cannibalising landscape) serves to reconcile both purposes. In the Queensland School Readers Book $V$, an illustration accompanying 'How the Child was Found' (the story considered earlier) highlights the landscape's seeming complicity in the lost child's plight (Figure 6). This image, unattributed to an illustrator, reveals a barren and lonely wilderness where a dead child lies beneath a dead tree. The viewer's eye is drawn along a line that highlights the pathos of (and the warning inherent in) the tableaux. The man and horses on the left direct us toward the child lying on the ground in a sleep-like posture. The child's face is turned toward the viewer. Meanwhile another man crouches over the child. There is symmetry in the two men either side of the child, both faces slightly concealed beneath broad-brimmed hats, each dipped toward the figure at their centre. Leaning over the child, these men both protect the innocent and frame the terrible moment of his discovery. While discovery is the illustration's focus, the

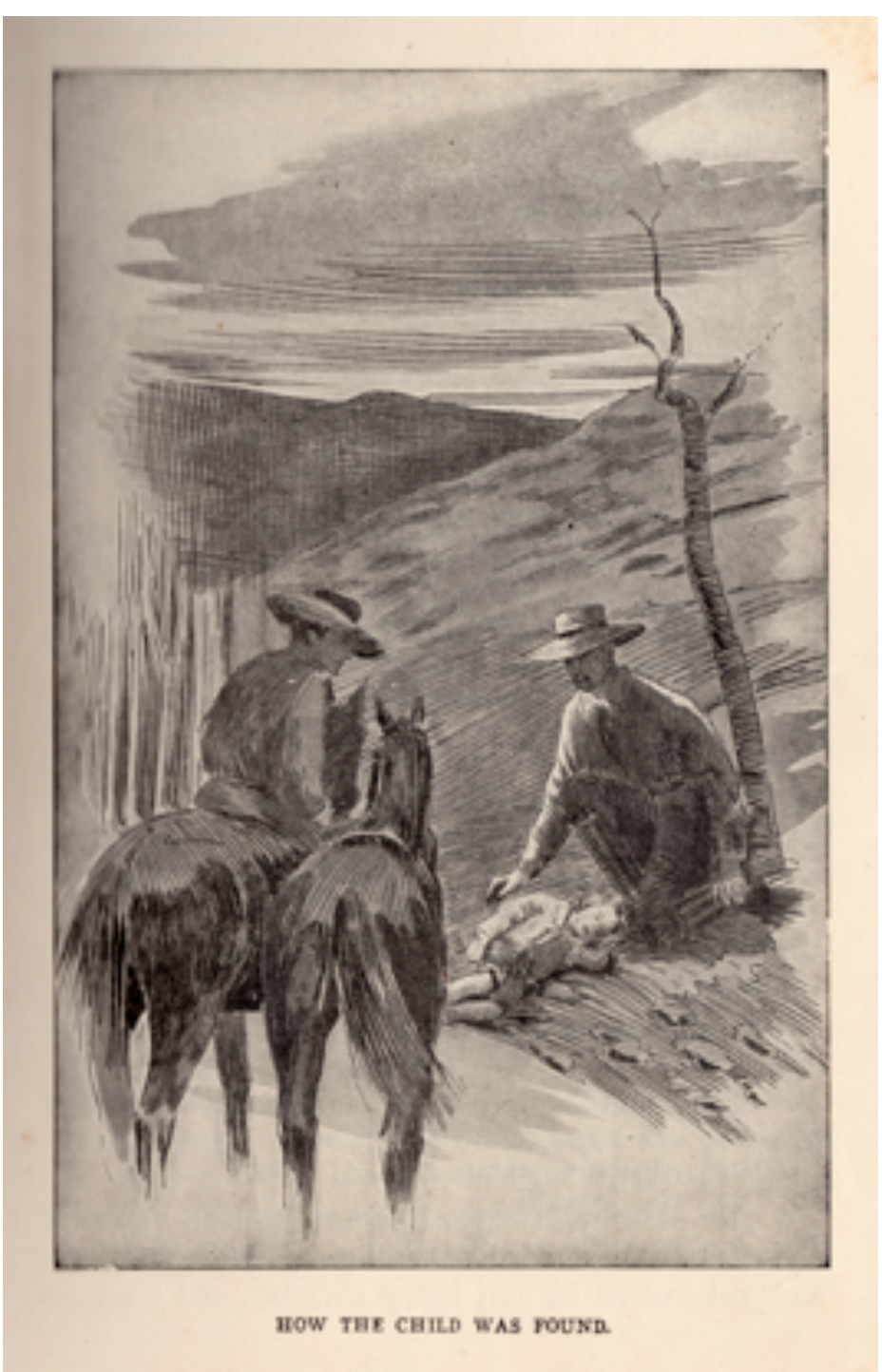

Figure 6. 'How the Child Was Found', Queensland School Readers Book V, 1913 setting is nevertheless a key element in constructing the 'sign' of the lost child as a central coding within a story of nation. Behind the boy and his 'rescuer', the dead tree draws the eye upward and out into the wilderness itself. It is the emptiness 'out there', the fear of the consumptive power of the landscape and all it represents that is 
the end point of the viewer's experience of this illustration. And it is this anxiety that informs our understanding of the image.

A very similar imaging of the lost child appears in The New Australian School Series Fourth Book (New South Wales) (Figure 7). Accompanying Marcus Clarke's story 'Pretty Dick', G. W. Lambert's illustration focuses on the moment of discovery, where the child is found dead in the midst of a hostile natural environment. Nature's malevolence is evidenced in the flock of crows circling nearby. In Lambert's drawing Pretty Dick appears at the bottom left of the frame, his face hidden from view as he lies face down, his head resting on his arm. It is Dick's father who dominates the image. His fists are clenched and his face is upturned as though appealing to a higher power as he kneels above his son. The father's hat lying discarded in the long grass points to his haste and desperation in reaching the boy. [1908?]

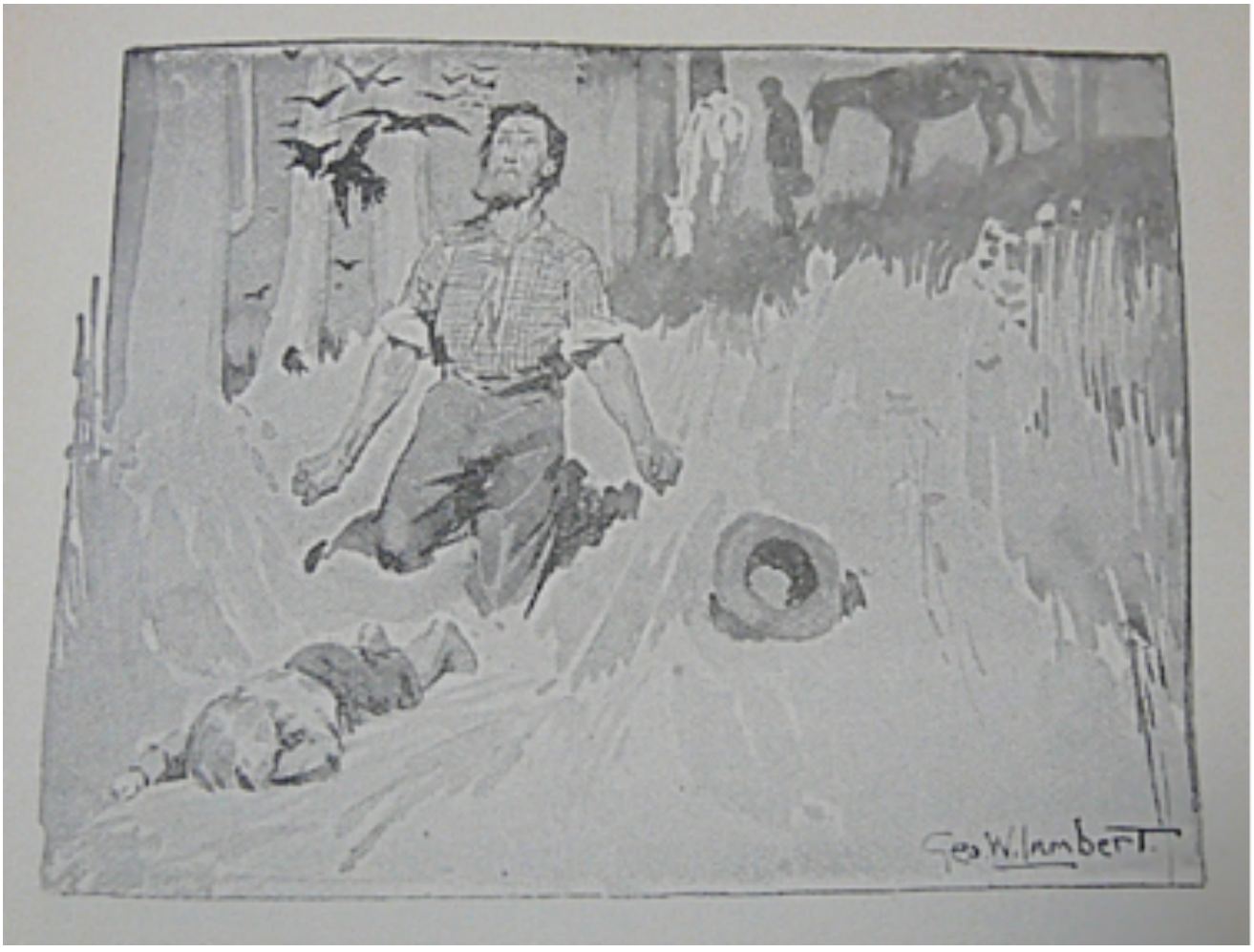

Any recuperative power located in the white man's ability to discover the child is simultaneously undermined by his inability to find the child alive.

Meanwhile, in the background, alongside two grazing horses, another figure respectfully turns away from this display of grief. The open space in which the scene is depicted, similar to the open hillsides of the previous illustration in the Queensland Reader, is in stark contrast to the claustrophobic bush depicted in the drawing of the Duff children. Yet landscape is important to each - it seduces the children, drawing them away from their families and into the wilderness, and ultimately, it betrays them. In each of these illustrations, national anxieties are revealed (just as they are expounded in the written text of the stories). These anxieties are about Australia's claim to a child-like innocence in relation to the discovery and settlement of the country, and anxieties about the unknown, uncivilised nature of the 'native' landscape and its unquenchable appetite.

Just as the trope of the bush-lost child is a central coding of School Readers, the figure of the (lost/found) child and the way in which he or she is interwoven with ideas about nation resonates 
across Australian fiction. To take a more contemporary example then, Andrew McGahan's Miles Franklin award-winning The White Earth (2004), is specifically concerned with stories of self (both personal and national histories). The novel explores notions of belonging and inheritance during what was, for some, a particularly unsettling political period in Australian history, the recognition of Aboriginal land rights. It is especially significant that The White Earth culminates in a disturbing sequence in which the central child protagonist William becomes lost while searching for what his uncle deems to be the key to his inheritance, a connection with the land itself, or, more profoundly, the ability to hear the land and its story. At the behest of his uncle, a man who repeatedly refers to an intimate knowledge of and spiritual connection with the station he now owns, William has been sent out to hear the land speak to him, unbeknownst to his mother or aunt: 'You can't lie to me, Will. You feel this country calling. I know you do' (McGahan 2004, p.296). While lost, William, suffering from a debilitating ear disease, is greeted by ghosts and feverish visions from the station/nation's past, the madness of an isolated and murderous shepherd, a starved and doomed explorer and, finally, a bunyip whose 'great eyes held the memory of all this, and of far more' (p.316). Ultimately, this creature allows William to read, through it, further traces on the landscape. The bunyip reveals to William the dead original inhabitants of the station, a group of Aboriginal men and boys killed by William's great uncle. As well as the suppressed memories and histories that this section of the novel represents and explores, this episode reveals the mystery at its heart. The child figure exerts a particularly potent influence in a literary and visual consciousness that, while speaking to both our anxieties and aspirations, is a consistently important way to portray and read a story of national growth. Tracing the story of the child is, after all, dependent on successfully reading the significance of those marks left behind.

School Readers undoubtedly encode stories of origin and development, but just as often, these stories are marked by gaps and inconsistencies. Thus, in reading the symbol of the child, especially as he or she figures in a metanarrative of national growth, I am alert to ill-fitting, mismatched or elided elements as well as for those that neatly fit together in dominant and appealing thematic geometries. In all the texts analysed here, the central male and female child protagonists are imbued with the nation's innermost cultural anxieties and desires. Across School Readers, the literary and visual production of children and childhood both excavates and suppresses concerns about claims to legitimacy and inheritance. This ambivalence is most strikingly manifested in stories and images of children either educated or swallowed by the bush. In conclusion then, I do not wish to suggest any singular reading of such a multilayered and unstable national story. Rather, I wish to draw attention to this rich field of research. It is possible to go back to school Readers to ascertain the kinds of values they apparently represented, what contradictions and inconsistencies underpinned the literary promulgation of these values, and ultimately, how questions of nation, nationness and national literatures were framed, perpetuated and supposedly, resolved. Opening the archives and re-reading school Readers allows us to revisit and critique those familiar stories we have long been taught to tell ourselves. 


\section{Endnotes}

${ }^{1}$ It is more difficult to date the introduction of the New South Wales Readers, the New Australian School Series. In their study, Firth and Darlington suggest the Fourth Reader was first published about 1908 (1993, p.81). In Firth's sole-authored article, a publishing date of about 1899 is given (1970, p.149). The Deakin University Textbook Collection and the National Library of Australia date Readers in this series from 1903 to [191?]. It would appear, however, that the production and use of the New South Wales Reader series preceded that of the Queensland series in 1913-14. As Spaulding writes: "It is likely that the readers were reprinted at various times early in the twentieth century" (2005, p.130).

${ }^{2}$ The various revisions and reprints mean that tracing the genealogies of school reading series can be a significant challenge. Similarly, because the Readers were produced cheaply to be used in schools (and subsequently handed down among family members), rather than displayed on shelves, entire sets of original School Readers can be difficult to locate. During my research, I found the Deakin University Library textbook collection invaluable. I also accessed the Tasmanian Readers at the State Library of Tasmania and sought advice about the Western Australian reading series through the History Department of the Western Australian Museum.

3،"The Bush Schoolboy" was first published in the Bulletin in 1927.

${ }^{4}$ In Ethel C. Pedley's children's book, Dot and the Kangaroo (1899), a little girl lost in the bush is befriended by a kangaroo and other bush creatures.

5“The Old Bush School" is an extract from Fullerton's autobiographical Bark House Days, published in 1911.

${ }^{6}$ C. E. W. Bean's The "Dreadnought” of the Darling was originally published in 1911.

${ }^{7}$ Charles Kingsley's The Recollections of Geoffry Hamlyn was first published in 1859. The story in the Readers is from the thirtieth chapter of the novel: "How the Child was Lost, and How He Got Found Again ...". The chapter was published separately in Britain in 1871 as an illustrated book for children, titled The Lost Child (Pierce 1999, pp.13-14).

8“Pretty Dick" appears in Tasmanian Readers Grade V, in The Adelaide Readers Book V as well as in the New South Wales The New Australian School Series Fourth Reader. This repetition is significant in what it suggests about the story's resonances for a narrative of national growth as it appears in Readers across Australia. Clarke's story first appeared in The Australian Magazine: A Colonial Monthly in April 1869. It was later reproduced in Clarke's Australian Tales, 1896.

${ }^{9}$ In the NSW version of this story, published in The New Australian School Series Third Reader, the mother suggests that the black children playing on the other side of the river are akin to pixies: 
"'Who are the children that play across there?'

'Black children, likely.'

'No white children?'

'No, my child, none but pixies. Don't go near them; they'll lead you on and on, nobody knows where,",

([n.d.],73).

${ }^{10}$ "Lost in the Bush" has had many manifestations as both a print and visual text. The version that appears in The Victorian Readers Fourth Book is based on Reverend P. W. Fairclough's retelling of the story as it appears in the children's column of The Southern Cross, an Australian weekly religious magazine. According to the notes included in the fourth Reader, "some local details have been added by Mr. Beaumont T. Pearse, who was once a teacher in the Horsham school" (1930, p.166). For more information about the provenance and the various incarnations of this story, see Torney, pp.27-29. "Lost in the Bush" also appears in The Adelaide Readers Book II although it is narrated differently in this version. While recounting the story to his grandchildren, an elderly man gives a first-person account of the children's ordeal. Despite the suggestion that the narrator knew the Duff children and the story first-hand, the account is of the same provenance as the version that appears in the Victorian Reader (based on Reverend P. W. Fairclough's narrative). It is likely that the Adelaide story is based on the text published in The School Paper (Victoria) in 1908 as "Lost in the Bush" and subsequently republished in the paper in 1923 (Torney 2005, p.30).

\section{References}

The Adelaide Readers Book II. (1925) Melbourne, Macmillan.

The Adelaide Readers Book V. (1928) Melbourne, Macmillan.

Bradford, C. (2001) Reading Race: Aboriginality in Australian Children's Literature. Carlton, Melbourne University Press.

Firth, S. G. (1970) 'Social Values in the New South Wales Primary School 1880-1914: An Analysis of School Texts', in R. J. W. Selleck (ed) Melbourne Studies in Education. Carlton, Melbourne University Press, pp.123-59.

Firty, S. G. \& Darlington, R. (1993) 'Racial Stereotypes in the Australian Curriculum: The CaseStudy of New South Wales', in J. A. Mangan (ed) The Imperial Curriculum: Racial Images and Education in the British Colonial Experience. London \& New York, Routledge, pp.7992.

Heathorn, S. (2000) For Home, Country, and Race: Constructing Gender, Class, and Englishness in the Elementary School, 1880-1914. Toronto, University of Toronto Press.

Higgonet, A. (1998) Pictures of Innocence: The History and Crisis of Ideal Childhood. London, Thames and Hudson.

Lawson, Alan. (2004) 'The Anxious Proximities of Settler (Post)colonial Relations', in J. Rivkin \& M. Ryan (eds) Literary Theory: An Anthology. Malden, MA, Blackwell, pp. 1210-1223.

Martin, S. K. (2007) "Us circling round and round": The Track of Narrative and the Ghosts of Lost Children in Such is Life.' Journal of the Association for the Study of Australian Literature: Spectres, Screens, Shadows, Mirrors Special Issue, 77-93.

McGahan, A. (2004) The White Earth. Crows Nest, Allen and Unwin. 
New Australian School Series Third Reader. [n.d.] Sydney and Brisbane, William Brooks.

New Australian School Series Fourth Reader. [n.d.] Sydney and Brisbane, William Brooks.

Pierce, P. (1999) The Country of Lost Children: An Australian Anxiety. Cambridge, Cambridge University Press.

Queensland School Readers Book V. (1913) Brisbane, A. J. Cumming, Government Printer.

Spaulding, R. (2005) Poetry and Tasmanian Institutions of Learning 1840-1950. Unpublished PhD dissertation. University of Tasmania.

The Tasmanian Readers Grade V. (1933) Melbourne, Education Department Tasmania.

Torney, K. (2005) Babes in the Bush: The Making of an Australian Image. Fremantle, Curtin University.

Turner, E. [1894] (1994) Seven Little Australians. Camberwell, Penguin.

The Victorian Readers Second Book. (1930) Melbourne, H.J. Green, Government Printer.

The Victorian Readers Fourth Book. (1930) Melbourne, H. J. Green, Government Printer.

The Victorian Readers Fifth Book. (1930) Melbourne, H. J. Green, Government Printer.

The Victorian Readers Sixth Book. (1929) Melbourne, H. J. Green, Government Printer.

The Victorian Reading-Books Eighth Book. (1928) Melbourne, H. J. Green, Government Printer.

\section{SOCR}

\section{Biographical Note}

Jane McGennisken completed a PhD at the University of Tasmania in 2009. She currently teaches English at St Mary's College in Hobart where she remains passionate about the intersections between Australian literature, children's literature and education. Email: janemcgennisken@gmail.com 